\title{
VALUE CHANGE IN JAPAN
}

\section{GISELA TROMMSDORFF \\ Technische Hochschule Aachen \\ F.R. Germany}

\begin{abstract}
This study explores the relationship between socioeconomic change and value change. The general assumptions of unidimensionality of modern and traditional values and their exclusive character is questioned on the basis of available data from surveys carried out in Japan and in the West. Traditional values in Japan obviously change in some respect, but remain stable in other aspects. The process of changing values seems to cause internal conflicts for certain subgroups such as women and adolescents. A comparative analysis can demonstrate that some Japanese values seem "modern" or "post-materialist" for the West, but they are part of the traditional Japanese value system. Such "modern" values fulfill different functions in different cultures. A theoretical framework for the study of social change and changing values is proposed, focusing on macro- and microlevel processes of change.
\end{abstract}

\section{INTRODUCTION}

Central questions in theories of modernization are: What kinds of values and attitudes are related to the process of modernization? Are traditional values an obstacle for modernization? Should they be replaced by modernity values?

Several studies answer these questions by equating modernization with Westernization (Lerner, 1974; Levy, 1966). During the process of modernization different cultures, each with a different value system, are assumed to converge and adopt democratic, modern values (Pye, 1966). Further value change is assumed for highly industrialized societies: Independent of their cultural background, these post-industrialist societies should develop post-materialist (post-bourgeois) values (Inglehart, 1977; 1979; 1982).

The thesis of Westernization and convergence in modernizing countries has been challenged in recent comparative studies that took into account the specific value system of the modernizing state. Black (1975) has shown

Portions of this paper were presented at the Fourth Annual Scientific Meeting of the International Society of Political Psychology, 1981 in Mannheim. The author gratefully acknowledges the valuable comments of Ronald Inglehart on the first draft.

Requests for reprints should be sent to Professor Dr. Gisela Trommsdorff, Institut für Erziehungswissenschaft, RWTH Aachen, Eilfschornsteinstr, ?, F.R. Germany. 
that the process of modernization and its relation to traditional values in the West is very different from Eastern countries. In certain cultures, Westernization and modernization do not mean the same thing, and are not related to the same values (Dawson, 1967); tradition and modernity do not necessarily involve conflicting values and behavior (Gusfield, 1967); and modernization does not necessarily imply the decline of traditionalism (Almond, 1973; Eiser:stadt, 1966; Stephenson, 1968) or the convergence of different values (Austin, 1976). The assumed change from materialist to post-materialist values in advanced societies need not necessarily occur in the assumed unidimensional sequence (Flanagan, 1980; Ike, 1973; Inglehart, 1982).

Comparative studies thus may help to differentiate assumptions on the relationship between modernity and traditional values. Such comparative studies should include societies that are comparable with regard to their economic position but different in their cultural values. It is asked here: Have traditional values changed in Japan during the period of her enormous, political, social, and economic change? And, if so, how far? Do the present Japanese values differ from the "modern" values of (post-) industrialized countries in the West?

Values are understood here as subjective generalized orientations of human beings, which-under certain conditions-can determine social behavior. Values and social change such as modernization are presumably interdependent. On the one hand, it is assumed that values can determine political and economic change and related individual behavior; on the other hand, values might change as a consequence of changed socioeconomic conditions. In this case, value change may serve as an indicator for modernization, or more generally, for social change.

\section{INFLUENCE OF VALUES ON SOCIAL CHANGE}

The impact of values on economic development has been demonstrated impressively by Max Weber (1965) in his study on the Protestant Ethic.

For the Japanese case, it can also be shown that certain traditional values served as a basis for rapid modernization. In 1853, after 200 years of isolation from the rest of the world, Japan was violently intruded by the West, and could easily have become a colony of the United States. Japan fought against dependency from the West by means of vigorous industrialization and economic development. How had this abrupt change from agrarian production to industrialization, and the concurrent changes in social and political behavior, including the emergence of new social institutions, been accomplished?

The extremely fast and successful Japanese industrial revolution can be seen as being based on two conditions: the import of Western technology and the activation of traditional cultural values, and the "Japanese spirit," 
imposed from the top (Reischauer, 1970). Though a new political system was introduced in 1868, the basic social and cultural conditions were retained and reinforced (Sörbom, 1981). Industrialization was initiated by the state while consequently restoring the traditional values (Shintoism, Buddhism, and Confucianism) in all domains of life. The traditional Confucian values and kinship structure of group solidarity (ie) and obligation (giri), loyalty and obedience to authority, belief in seniority, filial piety and mutual dependence were incorporated in nonkinship relations. Social relationships were modeled according to the principles of the patriarchal and paternalistic family (cf. Hsu, 1975: iemoto). Group solidarity, obedience, loyalty, self-sacrifice, and harmony served as the moral code for social relations (giri-ninjo); and the traditional Samurai Ethic of achievement, risk-taking, frugality, and selfdiscipline governed individual behavior (cf. Bendix, 1964; Dore, 1973; Jansen, 1970; Mae, 1981; Nakane, 1970).

These values allowed the government to mobilize the people and to legitimately demand and obtain extraordinary investments and achievements from them. Individual well-being was sacrificed for national progress. Furthermore, these values helped to prevent disruptive effects of the industrial revolution and served as an integrating force.

The Samurai Ethic and the Protestant Ethic have been conceived of as functional equivalents, in the sense that both value systems stimulated certain economic and social behavior constituting a condition for rapid economic development such as achievement and ascetic discipline (cf. Bellah, 1971; Bendix, 1964; 1966/67). However, there is one basic difference between these two value systems: The relative importance of individual success and well-being is most important in the West, but not in the traditional Japanese value system. The Samurai Ethic demands discipline and achievement to guarantee the success not of the individual but of the group. In Japan, the individual is first a member of the family or community; and the primary goal is the welfare of this group. Individual goals are considered to disturb the harmony of the group (McFarland, 1981). In other words, certain traditional values have been a functional prerequisite for modernization and economic growth in Japan.

Let us now turn to the other side of the coin. Even though traditional values have been instrumental for the rapid Japanese development, massive economic, political, and social changes might result in changes of traditional values.

\section{VALUE CHANGE AS A RESULT OF SOCIAL CHANGE}

In the following, intra- and intercultural comparisons will be presented to look for possible value changes in Japan during the last decades. Only those values will be studied which have been most central for the Japanese values system. 
After her unconditional surrender in 1945, a new period started for Japan. A democratic constitution was imposed by the Allied Forces; this was intended to dissolve the quasi-religious legitimation of political leaders and change political and social institutions according to the value system of Western democracies. During the following decades Japan experienced enormous economic growth and eventually occupied a leading position in the world market. Economic well-being finally reached the individual households, and changed consumption patterns, lifestyles, educational status, and several other indicators of social and economic well-being (Loercher, 1976).

Such political, economic, and social change might well have created conditions by which traditional values become obsolete. Furthermore, one might expect conflicts between the intrusion of modern values from the West and Japanese traditional values. At least from the Western viewpoint, the status of a modern industrialized nation should be incompatible with certain traditional values. Particularistic values, the seniority principle, and paternalism in work organizations should hinder mobility, individual aspirations and creativity. Obedience to authority should contradict democratic values and individual responsibility.

From the aspect of some modernization theories these traditional values should be dysfunctional for economic progress and should therefore change. Furthermore, in a highly industrialized society, materialist values should be replaced by post-materialist values such as participation and self-fulfillment (Inglehart, 1977).

In his attempt to study value change (and cleavages) in Japan, Flanagan $(1979,1980)$ has focused on the change of value preferences in four dimensions: (1) frugality to self-indulgence, (2) piety and selfdiscipline to permissiveness, (3) conformity to independence, and (4) acceptance of authority to self-assertiveness (Flanagan, 1980, p. 182). Since all four of these dimensions were empirically highly intercorrelated, Flanagan worked with a single scale, combining these value dimensions to measure traditional vs. libertarian values.

However, we will not use such a unidimensional conceptualization of values here. Presumably, neither traditional nor modern values are monolithic systems but rather consist of several variables that carry certain cultural meanings and specific social functions (cf. Gusfield, 1967).

According to our description of traditional Japanese values, at least the following variables constituting the core of the traditional Japanese value system should be studied.

1. Acceptance of authority (scope, basis, and behavioral consequences of authority):

(a) trust in authority;

(b) belief in seniority;

(c) belief in paternalism; 
(d) obedience and devotion to authority; conformity; filial piety; mutual dependence.

2. Status of women.

3. Group solidarity vs. individualism:

(a) self-discipline and frugality;

(b) priority of the group's or nation's interest while disregarding or sacrificing individual advantages for the sake of the group.

\section{Acceptance of Authority}

The scope, basis and behavioral consequences of the complex value to accept authority in Japan could be described by the following more specific values which are part of the traditional kinship system in structure and content: (a) acceptance of decisions made by the leader; (b) belief in seniority as a legitimate basis of social status; and (c) strict obedience to authority. As indicators for these specific values we will mainly use answers to questions from a longitudinal study on the "Japanese National Character" (the data are based on a nationwide sample survey repeated every 5 years; face-to-face interviews were conducted with 3,000 to 4,000 persons aged 20 years and older, selected by the probability sampling method [breakdowns for sex, age, and education]) (Hayashi, Nishira, Suzuki, Mizuno, \& Sakamoto, 1977; Nishihira, 1974); and the Second World Youth Survey (Youth Bureau, 1978). (This is the second survey since 1972, including 11 countries. The surveys are based on stratified random sampling. Personal interviews with questionnaires were conducted between November 1977 and January 1978. The samples included 2,000 male and female adolescents between the ages of 18 and 24 in each country.)

What kind of value change can be traced by intra-and/or inter-cultural comparisons regarding these variables?

The traditional belief in absolute competence of the leader has drastically changed during the last 20 years. As can be seen by Figure 1, the traditional belief to leave things to the political leader is increasingly rejected over the years (Hayashi et al., 1977).

In contrast, hardly any change has occurred with respect to the belief that the legitimate basis of social status is seniority. Asked how they think promotions and salary increases should be decided (mainly by performance or mainly by seniority), Japanese adolescents (36.0\%) prefer mainly seniority as a basis for promotion; the comparison figures for West Germany and the United States being $14.3 \%$ and $14.0 \%$. On the other hand, West German (39.2\%) and American (44.9\%) adolescents prefer "mainly performance, but seniority also considered" to a higher percentage than Japanese adolescents (25.8\%) (Youth Bureau, 1978, pp. 52-53). 


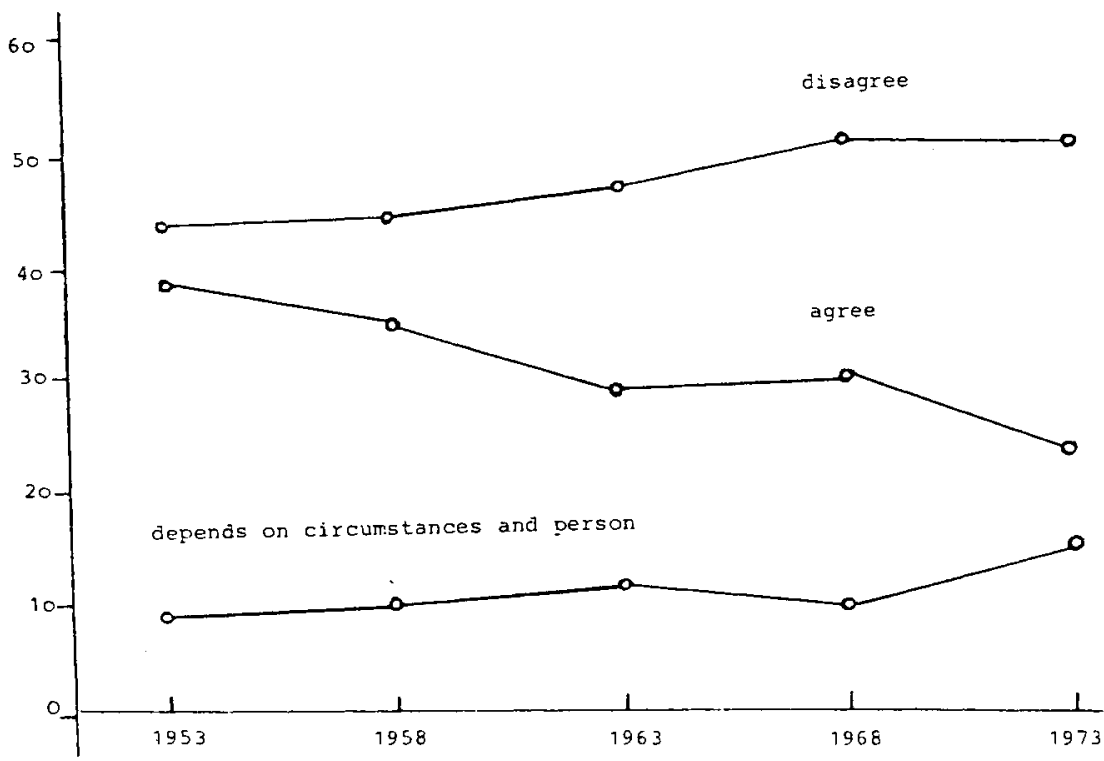

FIGURE 1. Leave Things to Polltical Leaders

The data show that a giri-ninjo type of behavior describing traditional social structures of mutual obligation and trust is still highly valued irrespective of respondents' age, sex, or education. To maintain personal friendly human relations is highly valued. The related belief that the supervisor should show active concern for one's private matters even outside work is accepted by more than $80 \%$ of all respondents with hardly any change during the last 20 years (Hayashi et al, 1977, p. 15). The hierarchical relation between supervisor and employee reflects the traditional father-son or teacher-student relationship with its mutual obligation of giving protection and filial piety (iemoto, Hsu, 1975, pp. 59ff). This type of relation is based on the notion of ie (house, state, group, family) and dozoku (community).

In the same line, the traditional value of obedience to authority is still a dominant educational goal-more important than the value of independence. Hardly any value change has occurred in Japan in this respect while an enormous change took place in Western nations such as the Federal Republic of Germany (even when taking into account significant effects of social class as reported in the "Zweiter Familienbericht"; [Der Bundesminister für Jugend, Familie und Gesundheit, 1975]) (see Table 1).

Obedience and independence as educational goals have different functions for the development of the personality according to the context of cultural values where these goals are practiced. Child-rearing associated 
TABLE 1

Educational Goals In Cross-Cultural Comparison

\begin{tabular}{lccc}
\hline & $\begin{array}{c}1953 \\
(\%)\end{array}$ & $\begin{array}{c}1968 \\
(\%)\end{array}$ & $\begin{array}{c}1973 \\
(\%)\end{array}$ \\
\hline $\begin{array}{l}\text { Japan* } \\
\text { Independence }\end{array}$ & 16 & 20 & 22 \\
$\quad$ Discipline, obey authority & 63 & 68 & 66 \\
& 1951 & 1965 & 1972 \\
Federal Republic of Germany * & & & \\
$\quad$ Independence & 28 & 31 & 45 \\
$\quad$ Discipline, obey authority & 25 & 19 & 14 \\
\hline
\end{tabular}

"Source: Hayashi et al., 1977.

*-Source: EMNID, 1972.

with values of authority is functional for the cognitive development of the Japanese child; however, for the child in the U.S. it is dysfunctional. The reverse is true for the value of independence in child-rearing (Azuma, 1980). (Interestingly, in ordinary child-rearing, much less distinct appeals to authority are used by the Japanese than by the American mother [cf. Conroy, Hess, Azuma, \& Kashiwagi, 1980].)

These studies underline that single values only have a meaning in the context of the broader value system. Traditional values, i.e., seniority and obedience to authority, still occupy a central position in the present Japanese value system, even though today decisions made by authorities are increasingly subjected to critical assessment.

\section{Status of Women}

Closely related to traditional patriarchal values is the belief that women are inferior to men. This belief is part of the Buddhist and Confucian values. Before Confucianism influenced Japanese thinking, women had considerably high status: Until at least the twelfth century, they had property rights, rights of inheritance, and a much higher position in the family; and before, in prehistorical and early historical society, the Japanese woman must have occupied a high position. However, Japan has been a patriarchal and patrilineal society since history has been recorded (Mae, 198I; Pharr, 1977). After Japan's surrender, the occupation gave women guarantees for equality in the new Constitution of 1947 , which are in some aspects more progressive than in many other democratic countries. In the meantime, many changes have occurred for women: increased access to higher education, to employment outside the home, and to consumption and material well-being. 


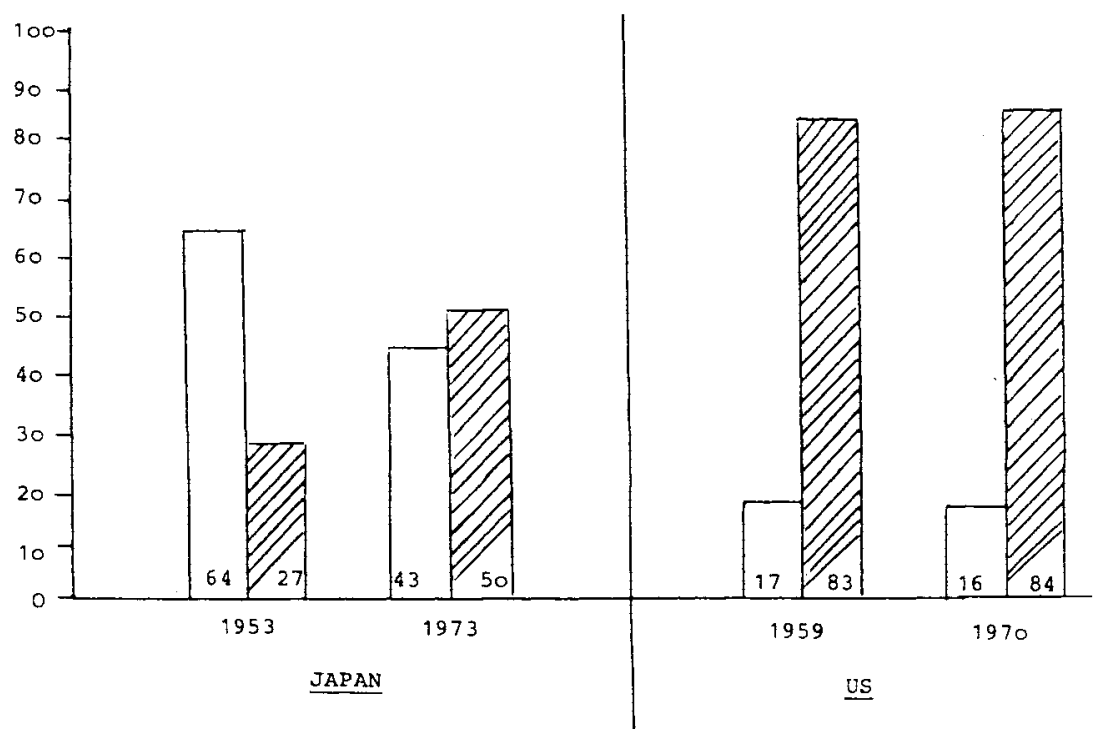

$\square$ prefer son
Z7ד prefer daughter
Source: Foreign Press Center Japan, 1977.

FIGURE 2. Percentage of Women Who Prefer a Son/Daughter as Child

In which way did values relating to the role of women change in the meantime?

In general, Japanese women believe that the female role is less valued than the male role. This is indicated by the belief of the majority of Japanese women that men and women have unequal status in "commonly accepted beliefs and practices" and at work (Foreign Press Center, 1977).

From the women's viewpoint, their social status is still dramatically lower than that of men. In 1953, the majority of Japanese mothers wanted a son as a child (64\%); only $27 \%$ preferred a daughter. Sons are more highly valued than daughters-quite different from the West. However, this preference declined quite dramatically during the past 20 years (see Figure 2). In 1973, $43 \%$ preferred a son, and $50 \%$ wanted a daughter. The comparable figures for the United States are $16 \%$ and $84 \%$.

The same pattern of higher value for sons can be seen in the plans and goals of parents for their children. The majority of parents want their son to study at a university ( $57 \%$ ) as compared to only $25 \%$ of the parents who plan the same educational privilege for their daughters. Furthermore, 
TABLE 2

Way of Life Desired by Mothers for Their Chlldren

\begin{tabular}{lcc}
\hline & $\begin{array}{c}\text { For girls } \\
(\%)\end{array}$ & $\begin{array}{c}\text { For boys } \\
(\%)\end{array}$ \\
\hline Follow majority opinion and suppress individual ideas & 78 & 54 \\
Assert personal ideas & 17 & 41 \\
Try hard and do not fall behind others & 40 & 63 \\
Relax and enjoy life & 54 & 32 \\
\hline
\end{tabular}

Source: Foreign Press Center Japan, 1977

the educational goals of mothers for their sons differ from goals for their daughters. Boys should try hard to be successful in their achievements, and they should be assertive, while girls should enjoy life and suppress individual ideas (Foreign Press Center, 1977) (see Table 2).

These gender-specific values are socialized effectively, as one can see from the answers of adolescents. Hardly one third reject $(31.7 \%)$ while $50.4 \%$ accept the traditional belief that males should work and females should stay at home. In the Federal Republic of Germany, nearly two thirds $(58.7 \%$ ), and in the U.S. $71.4 \%$, reject this statement (Trommsdorff, 1981; Youth Bureau, 1978, p. 9). Even the majority of Japanese women (in 1974: $80 \%$ ) believe that women should rather stay at home, although $46 \%$ of all women were actually working (Foreign Press Center, 1977).

This enormous discrepancy between values and behavior might be an indicator for internal conflicts of Japanese women. Such conflicts can also be inferred from the relatively low percentage of women accepting their sex role. In 1953, only $27 \%$ of Japanese women preferred to be born as women, and $64 \%$ preferred to be born as men. Twenty years later, in $1973,51 \%$ of the women accepted their sex role (as compared to $84 \%$ in the U.S.); however, $43 \%$ still would prefer to have been born as men (cf. Hayashi et al., 1977, p. 7).

Though value changes relating to the gender role are enormous, the number of Japanese women accepting their role is still small. This low self-esteem shapes their values and their educational goals for their daughters and sons and seems to perpetuate patriarchal values to the next generation. Contrary to these observations, the Japanese women are described to be quite powerful in the family domain (Linhart, 1976). To give an example, child-rearing is the main responsibility of the mother; she has to control the children's achievement in school and she decides on the family budget (cf. Linhart, 1976; Trommsdorf, 1979; Vogel, 1979). Furthermore, regarding the relations between men and women, men are often described as being dependent on women because of their basic 
desire for amae-a need for indulgence that has been experienced during childhood in relation to the mother (cf. Doi, 1973; Mae, 1981; Morsbach, 1977).

However, the still prevalent limitation of women's influence on family matters follows the traditional belief in a patriarchal social system.

Group Solidarity vs. Individualism. Frugality and an ascetic life were basic values for the traditional Samurai, and money was considered as unclean before the Meji period. However, since many Samurai were given leading positions in industry and political decision making, this negative evaluation of money has decreased, and achievement has more and more been measured by material success. Therefore, it is not surprising that $65 \%$ of the Japanese parents in 1953 agreed that "teaching children money is most important." This "materialist" value has been shrinking during the last 20 years: In 1973, 21\% less agreed with this goal (Hayashi et al., 1977).

Inglehart (1982) conceives of this value change as an indicator for a shift away from materialist values. However, this author cannot agree with this interpretation when looking at the $44 \%$ who support this valuea number still exceeding the number of people opposing this value or the percentage of persons in the U.S. (5\%) accepting this goal.

Furthermore, it is unclear whether these items "to get rich" and "to teach children that money is most important" are suitable indicators for materialist values. Both items measuring material success and achievement might, however, be subjectively perceived as means for nonmaterial goals, such as acquiring the necessary preconditions for living a life that suits one's own interest-a goal that has been interpreted as an indicator for post-materialist values.

\section{TABLE 3}

Group Orlentation and Indlvidualism as Values

\begin{tabular}{lccc}
\hline Question & \multicolumn{2}{c}{ Percentage of Adolescents inswering Question } \\
\hline $\begin{array}{l}\text { People have different goals in life. } \\
\text { Which of the following on this } \\
\text { card is closest to yours? }\end{array}$ & Japan & $\begin{array}{c}\text { Federal Republic } \\
\text { of Germany }\end{array}$ & United States \\
\hline $\begin{array}{l}\text { Please choose one: } \\
\text { To get rich }\end{array}$ & 35.4 & 9.0 & 6.2 \\
To acquire social position & 5.8 & 17.3 & 5.1 \\
To live as I like & 41.2 & 60.6 & 77.3 \\
To work on behalf of society & 6.8 & 5.5 & 9.5 \\
No answer & 10.8 & 7.5 & 1.8 \\
\hline
\end{tabular}

Source: Youth Bureau, 1978, pp. 68-69. 
Here, one may see how misleading it may be to generalize from single selected items on complex values, ignoring the meaning of such specific items in the complex cultural and individual value system.

In the same line, a comparison of Japan and other industrialized societies shows that Japanese adolescents are still following materialist goals to a larger extent than German or American adolescents (35.4\% vs. $9.0 \%$ and $6.2 \%$ respectively) (Youth Bureau, 1978, pp. 68-69) (see Table 3).

The priority of group interests was a central traditional value in the Samurai Ethic. A comparison of the values of Japanese adolescents from 1930 to 1970 demonstrates very clearly that "a life of serving the society" has been somewhat rejected, while "a life that suits one's own taste and interest" is increasingly preferred (Figure 3). However, when comparing

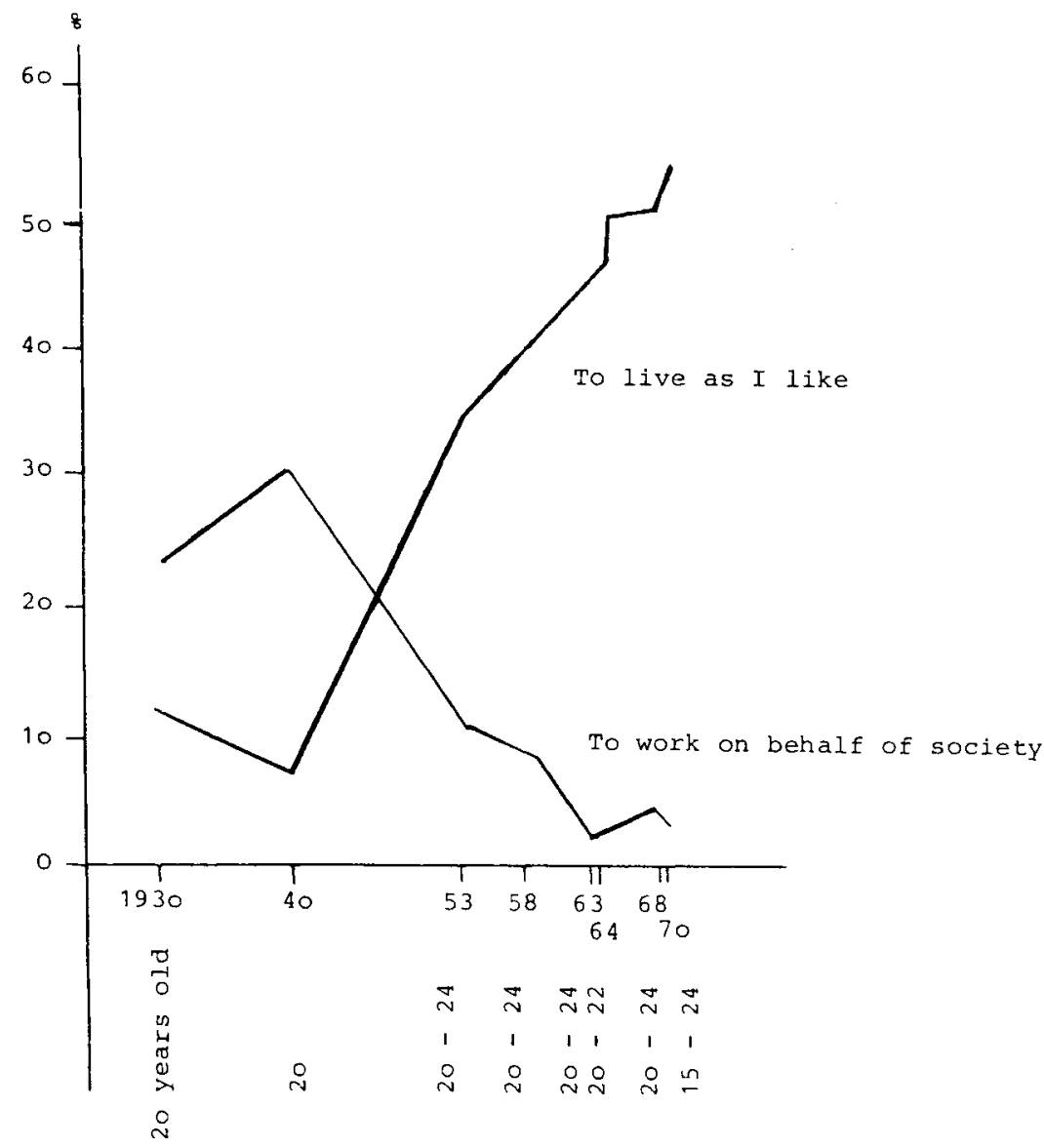

Note: see table 3 for the questions asked. Source: Hayashi et al., 1977.

FIGURE 3. Change of Values in Japanese Adolescents from 1930-1970 
Japanese with adolescents from West Germany and the United States, it becomes obvious that the Japanese still value self-actualization much less ( $41.2 \%$ vs. $60.6 \%$ and $77.3 \%$ respectively) (Youth Bureau, 1978, pp. 68-69) (see Table 3).

Related to the value of group solidarity is, of course, the readiness to invest activities for the improvement of the group. The readiness to participate in political activities such as voting or in nonconventional behavior such as demonstrations or signing petitions is not very different in Japan and West Germany-though it is much less pronounced than in the U.S. However, the readiness to escape from society and to become a drop out when dissatisfied with society is much greater for Japanese adolescents (13.4\%) than for U.S. (5.4\%) or German (4.8\%) adolescents (Youth Bureau, 1978, pp. 61-62) (see Table 4).

Here we can observe an enormous change in Japanese values: The former tight integration into the community has somewhat decreased and lost its attractiveness. A life of serving the society is no more a primary goal; instead, individual interests are more preferred. If dissatisfied with society, there is some probability to turn one's back.

\section{Japanese Value Change and the Model of Post-Materialism}

How can these stabilities and changes in the traditional value system be interpreted?

The most prominent theory to explain and predict value change in highly industrialized societies has been advanced by Inglehart (1977) in his description of the "Silent Revolution." According to this view, it is assumed that material (bourgeois) values are declining and are replaced by post-materialist (post-bourgeois) values in highly industrialized nations.

Inglehart partly follows the work of Bell (1973) on the post-industrial society; Bell observes basic changes in the working and living conditions, which may lead to increased possibilities for personal fulfillment outside of work. According to Inglehart, economic well-being experienced in these post-industrial societies effects basic value change toward post-materialist values.

Inglehart's theory is based on three assumptions. First, scarce goods are always valuable. That is why economic well-being loses its attractiveness in an affluent society. Second, material and physical needs are more important in a hierarchy of values than nonmaterial needs. Inglehart here refers to the model of need fulfillment by Maslow (1954). Increasing economic well-being and physical security fulfill sustenance and safety needs. Thereby, materialist values or the need for physiological survival and security become less important and are replaced by values for selffulfillment, belonging, aesthetics and creativity. And, third, values are socialized during adolescence. A generation of post-materialists can grow 
up when satisfaction of physical and material needs has been experienced during adolescence.

Inglehart's (1977) thesis (criticized and supported) has stimulated much interesting research, which, in fact, partly demonstrates the predicted value change in the West (e.g., Barnes, Kaase, et al., 1979). A critical discussion of his approach cannot be presented here. But, the question is asked: How far can the assumed value change for highly industrialized countries toward post-materialism be observed in Japan?

In his study on the relationship between socioeconomic change and value change in several highly industrialized countries, Inglehart (1979) can demonstrate a correlation between level of economic well-being in a society and percentage of nonmaterialists $20-26$ years later. Japan was lowest in GNP per capita in 1950 and counted 1 post-materialist in 9 materialists in 1970-1976. Germany had a much higher GNP in 1950 and a 4:1 ratio; the relatively highest GNP occurred in the U.S., and the 1970-1976 ratio between materialist and post-materialist was about 2.5:1. In spite of this study, Inglehart (1982) believes that post-materialist values are expanding in Japan since postwar economic progress.

Today, the economic status of Japan is comparable to-and, as far the average annual growth rate (of GNP) is concerned, even exceeding-the West. But possibly one has to differentiate whether economic prosperity occurs on the individual, aggregate, or national level. In Japan a considerable time lag exists between the individual and the national experience of economic success. Only recently, the consumption pattern of individual households and nonmonetary social indicators of well-being changed dramatically and have become comparable to the West (Loercher, 1976).

Even such differentiation may not help to support the assumption that economic well-being improves post-materialist values. A closer look at intra-societal variations in economic status shows that economic wellbeing in Japan does not necessarily induce the development of postmaterialist values. In his study on value and economic cleavages in Japan, Flanagan (1980) shows that materialists as compared to post-materialists are not primarily to be found in lower economic positions; on the contrary, the highest level of nonmaterialists occurs among the lowest income groups (p. 200) (e.g., farmers who belong to the most traditional groups). Though Flanagan's operationalization of materialist and postmaterialist is not the same as Inglehart's (1982), the basic values discriminating these two groups have been incorporated in Flanagan's instrument. Inglehart's assumption that economic well-being is a precondition for the development of post-materialist values thus cannot be supported by the Japanese data.

Let us now turn to some indicators for materialism and postmaterialism. Post-materialist values have been described by Inglehart 
(1977, 1979) as need for self-actualization, belonging, and participation, while materialist needs are described as need for physical security and well-being.

As has been shown, materialist values are still comparatively strong for Japanese as compared to German or American adolescents (Table 3), although Japanese parents today prefer this materialist value less as an educational goal than 20 years before. Furthermore, the nonmaterialist value of self-actualization is still much less pronounced for Japanese as compared to German or American adolescents (see Table 3).

Another indicator for post-materialist values is party preference. According to Inglehart (1982), post-materialists of all age groups in nine countries of the European community have a more pronounced preference for leftist parties than materialists (p. 530). In the same line, Flanagan (1980) in his study of value and economic cleavages in Japan, could demonstrate that-according to his traditional vs. libertarian scale-the preference for political parties in Japan follows the same pattern as in the West. Libertarian values gain in importance. However, the relationship between post-materialism and voting behavior in Japan is not as simple as might be concluded from Inglehart's studies. Other variables, such as occupation, economic, and value issues, modify the relationship between post-materialism and vote (Flanagan, 1980).

Another indicator for value change typical for post-industrial societies would be the kind of political participation. Kaase (1976) showed that post-materialists, as compared to materialists, prefer unconventional political behavior such as participating in demonstrations, and so forth. These observations are supported by results of the survey on well-being in 1978 in the Federal Republic of Germany (Siara, 1980) and by studies on other European countries (Barnes, et al., 1979).

However, when adolescents are asked what attitude they would take when dissatisfied with society, Japanese and German as compared to American adolescents would be less inclined to choose conventional means such as participating in demonstrations or writing petitions $(26.0 \%$; $32.2 \%$ vs. $61.5 \%$ respectively) (Youth Bureau, 1978, pp. 60-63) (see Table 4). Thus, a clear post-materialist behavioral preference for unconventional participation cannot be shown for Japanese--but neither can it be shown for German adolescents. This surprising result must be related to the relatively large number of nonresponses in both countries as compared to the United States. Thus, it remains unclear what kind of participation this "no-answer" group would actually prefer, and whether social sanctions might have prevented respondents from giving a definite answer.

In his study on "Economic Growth and Intergenerational Change in Japan," Ike (1973) has already partly refuted Inglehart's thesis on change toward post-materialism in highly industrialized countries for the Japanese case. Ike refers to some items from the national character survey in Japan 
TABLE 4

\section{Group Orientation and Individuallsm as Values}

\begin{tabular}{|c|c|c|c|}
\hline Question & \multicolumn{3}{|c|}{ Percentage of Adolescents Answering Question } \\
\hline $\begin{array}{l}\text { Suppose you are dissatisfied with } \\
\text { society, what attitude do you } \\
\text { think you would take? }\end{array}$ & Japan & $\begin{array}{l}\text { Federal Republic } \\
\text { of Germany }\end{array}$ & United States \\
\hline $\begin{array}{l}\text { Please choose one: } \\
\text { I will use my voting right but } \\
\text { nothing more. }\end{array}$ & 39.3 & 48.8 & 27.4 \\
\hline $\begin{array}{l}\text { I will actively resort to a variety } \\
\text { of measures, such as petitions, } \\
\text { letters of complaint, } \\
\text { demonstrations, strikes, etc., so } \\
\text { long as the means are permitted } \\
\text { by law. }\end{array}$ & 26.0 & 32.2 & 61.5 \\
\hline $\begin{array}{l}\text { I will resort to violence and } \\
\text { other illegal measures if } \\
\text { necessary. }\end{array}$ & 3.2 & 3.0 & 3.7 \\
\hline $\begin{array}{l}\text { I will become a drop-out from } \\
\text { society. }\end{array}$ & 13.4 & 4.8 & 5.4 \\
\hline No answer & 18.1 & 11.2 & 2.0 \\
\hline
\end{tabular}

Source: Youth Bureau, 1978, pp. 60-63.

and points out that life cycle and adult changes occurred in Japan beside some of the predicted intergenerational change. The picture of value change in Japan is rather complex, without a definite decline of materialist or increase of post-materialist values.

Inglehart (1982) admits that a clear pattern of increasing postmaterialist values is difficult to detect. He believes that such a pattern is obscured by still existing pre-industrial values (e.g., group orientation). Traditional values in Japan exist beside more modern values. Materialism in the $50 \mathrm{~s}$ co-exists beside pre-materialist values, and in the $60 \mathrm{~s}$ beside individualism and the rise of post-materialism.

In accordance with Inglehart (1982) one should distinguish between pre-materialist, materialist, and post-materialist values in Japan in order to understand value change more precisely.

However, it may not be correct to measure materialist values in Japan in the same way as in the West. What seems to be low materialism in Japan in respect to such indicators as low concern for wages or for control of criminality may be a consequence of pre-industrial values such as group solidarity (on account of which harmonious interpersonal relations and effective social control are established and have prevented threatening crime rates).

Another example for the need for culture-specific indicators for certain values is the assumption that participation serves to improve society, and post-materialists are more motivated to choose nontraditional activities. 
However, traditional means (such as voting) or nontraditional means can reasonably be taken into consideration only if one believes in one's own ability to change and improve society. The post-materialist theory neglects those people who do not believe in such ability, or who have decided not to actively participate in society. This group is relatively large in Japan. The percentage of adolescents who choose to become drop outs and use neither traditional nor nontraditional means of participation if dissatisfied with society is much larger in Japan than in Germany or in the United States (see Table 3).

This passive orientation may be related to a more pronounced belief of Japanese adolescents in their inability to control events as has been shown by Trommsdorff (1981). Nearly half of the Japanese (43.8\%) as compared to ony $30.9 \%$ of West German adolescents are convinced that success depends on luck or fate rather than on own activities (Youth Bureau, 1978, pp. 46-47). Japanese youth rather passively accept dissatisfaction with society than actively participate in changing the causes of their dissatisfaction. This attitude may be understood on the background of the traditional Japanese belief that the natural course of life should not be changed and interferred with by individual activities (Kaplan, 1981, p. 21). Furthermore, the strong belief in the prevalence of the group (at the expense of individual satisfaction) might still be influential even though this specific value has lost some of its importance. As long as related group values are so pronounced in Japan, a general belief in the power of the group will, presumably, foster a belief in external control, individual worthlessness, and retreat from active participation.

\section{DISCUSSION}

\section{Value Change in Light of Western Models}

The data presented here illuminate how difficult it is to explain value change in terms of simple models of change toward Western and postmaterialist values.

The studies on the national character of the Japanese reflect a complex picture which does not really fit to the Western model of value change through modernization. Traditional values such as the belief in filial piety, obedience to authority, paternalism, and the value of group solidarity are still very prominent; "materialist" values (such as teaching children that money is important) are relatively strong though declining; more modern values (e.g., individual well-being) are slowly adopted.

It is obvious that the traditional value system in Japan has been preserved in many important aspects, though now, as a leading industrial power, the country has undergone enormous economic change 
in a very short period of time. Here we may agree with Rokeach (1973) that central values are stable and resist social influences.

The data clearly show that traditional values need not at all contradict or hinder the process of modernization; on the contrary, in certain cultures, they may further and advance economic growth, and they may co-exist with so-called modern values. Thus, Bendix (1964; 1966/67), Eisenstadt (1966), Almond (1973), and Lepsius (1978), pointing out that modernization does not necessarily imply the loss of traditional values, come much closer to a realistic understanding of social change and changing values.

In the same line, the convergence thesis cannot be supported. An increasing development of Western "modern" values such as universalism, affective neutrality, conflict, egalitarianism, autonomy, and individualism cannot really be demonstrated for Japan. Austin (1976) even observed an increase of cultural differences between Japan and the U.S. except for similarities in achievement values. In spite of methodological problems (only highly educated persons above 30 years old were questioned; the validity of indicators for traditional and modern values was not tested), this study indicates that theories of social change and modern values developed in the West might not be useful for economically similar but culturally different societies.

Furthermore, the thesis of increasing post-materialist values in highly industrialized societies is not clearly supported for Japan. In spite of increased preference for post-materialist values (such as individuality) and decreased preference for material success, a unidimensional pattern of change toward post-materialist values does not occur in Japan-not even for the young generation. Even for adolescents, materialist values are still much stronger and self-actualization is still less valued than in the West.

One may ask if the pattern of value change in Japan follows different rules than in the West: In Japan, the value for self-gratification and individualization seems to be increasing; and this change may expand at the expense of group orientation (lke, 1973).

However, it seems too simple to assume a unidimensional occurrence of individualism vs. group orientation. It might very well be that individual interests partly are preferred at the expense of public interests; however, the need for belonging must not necessarily decline together with rising individualization.

Any such speculations on unidimensional value change-be it from traditional to modern, from materialist to post-materialist, or from group to individual values - seem to be too simple to explain the complex structures and processes that interrelate socioeconomic change and value change. Such changes should be studied while taking into consideration the specific meaning of certain values in the context of the given culture. 


\section{Value Change in the Cultural Context}

An interesting aspect of Japanese value change is that it seems to be inconsistent from the point of view of the West. Strong traditional values such as group solidarity, paternalism, strong personal relations between employer and employee, harmony, and familism are co-existing with quite modern values such as achievement and competition. Along with democratic values exist the beliefs in hierarchical social structures, in authority, obedience, and inequality of men and women.

Some values seem modern to the West but are very traditional for Japan; for example, democratic decision making in groups often implies time-consuming discussions in order to stabilize group harmony and achieve consensus on the issue in question. However, the last word in such decision making is expected to come from the leader. Competition is allowed to occur between groups, but not between members of the same group (cf. Dore, 1973; Linhart, 1976; Vogel, 1979).

Other traditional Japanese values such as group solidarity represent very modern, post-materialist values for the West. This value characterizes social relations in pre-modern Japan, and still is very dominant today (cf. Caudill \& Scarr, 1974) even though the goal to serve the nation's or community's interest is declining. The individual gains his/her personal security (well-being and identity) on account of his/her group membership. In the West, where individuality and autonomy have so long been cherished, such a value for solidarity, belonging, and integration in a group is increasing as part of post-materialist value change.

Does the partial decline of traditional values mean the coming of the post-materialist period in Japan?

This question seems false since, as we have seen, traditional Japanese values can be viewed as very modern and "post-materialist," and modern Japanese values as "materialist" from the Western point of view. The simple models of value change developed from Western perspectives do not fit into the Japanese case. Value change in Japan should be analyzed according to the specific cultural conditions there. These conditions give rise to a complex picture of partly changing and partly stable traditional values.

Since much of this change depends on the emergence of a younger generation, it seems necessary to study the conditions and processes of value socialization and change for adolescents.

The complex process of value change and value stability in Japan presumably induces conflicts for society and its members. Japanese adolescents especially seem to suffer from discrepancies between values introduced from the West and their own traditional beliefs. Such conflicting values may induce insecurity as to which values to choose and how to set priorities in everyday decision making. Neither the modern 
Western nor the traditional Japanese value system as such seem to be adequate for coping with present problems and anticipated future problems (Kaplan, 1981).

To give an example: Japanese adolescents are socialized to follow authorities, and not to decide independently or trust their own judgments (Nakane, 1970; Trommsdorff, 1984). Furthermore, since economic and occupational success is not primarily dependent on individual achievements at work but rather on seniority, and since group rather than individual activities are rewarded, the Western value orientation of individuality and autonomy is not really rewarded in the Japanese culture. A passive orientation and devaluation of personal control may arise in such a case of conflicting values-e.g., when Japanese traditional values of group obligation, on the one hand, and modern values of individuality on the other hand, both are experienced as inappropriate in the actual situation.

This may induce a belief that success is not dependent on individual efforts $-\mathbf{a}$ belief that traditionally resulted from the realistic attribution that only the efforts of the group could be the basis for everyone's (including one's own) success. But in the context of devaluated priority of the group and increased appreciation of individual autonomy, such a belief becomes distorted and shifts toward a generalized belief in external control. Such a belief in luck or chance rather than in personal competence (Trommsdorff, 1981) results in passivity and retreat. Therefore, it is not surprising that Japanese adolescents, to a relatively large percentage, rather choose to become drop outs if dissatisfied with society than to actively participate in constructive behavior to change society (see Table 4). The low value women attribute to their sex may in the same way contribute to their low interest in changing their status and the way they passively continue to accept their role. In the same line, the preference for one's own interests instead of investing one's energy on behalf of the society (Figure 3 ) may be explained as a consequence of conflicting values.

Once the trust in the value of group solidarity has been shaken, the preference for individual well-being becomes more prominent, but the latter cannot become a legitimate value as long as society still rewards the group and group solidarity. A possible result might be retreat and escape.

The question of future value change in Japan is difficult to answer because social and economic conditions are difficult to predict.

The impact of ecological and economic factors may hinder the development of "post-materialist" values in Japan in the near future if new and unexpected economic social and political problems are coming up after a period of enormous economic progress. Such problems (i.e., energy crises) may constitute severe restrictions and even negative sanctions as far as they would not allow people to conceive of their material property as a safe good. On account of such experience, physical 
and material safety may obtain a qualitatively new "materialist" value. These problems may evoke well-learned traditional activities and values that have been successful in the last centuries but can still be functional for coping with problems of today's society.

However, such interpretations are speculative and should be empirically tested in further research. The multidimensional relations between social change and changing values in the given culture should be analyzed much more precisely in further research. Such studies should be aware of the methodological problems involved in comparing values across nations and across time. One main problem to be solved is whether the indicators for social values are really measuring the same values across nations and between years. It might be necessary to use different indicators for the same but changing value. Here, the question of functional equivalence of indicators for time and cross-cultural studies comes up.

In the present study, only some selected subjective values were discussed, which were measured by answers to certain structured questions. The problem is whether the subjectively really relevant values have been measured by this method. Furthermore, it is unclear how far single items represent whole value areas; what the relationships between such values are; what their behavioral impact is; and given some behavioral impact, what its side effects and consequences for the change on the individual and social level would be.

Such methodological and theoretical questions can only be answered from the basis of a well established theory of social values which predicts the conditions, nature, and consequences of value change. Such a theory should take into account the following: (a) the exogenically produced value change (on account of changed social sanctions, reference groups, institutions); (b) the endogenically produced value change (which might occur on account of changed prevalence of needs); and (c) the intended and nonintended consequences of experienced value change on the individual and social level.

For future research, it seems fruitful to study value change (or stability) and interrelations between values and social change on the basis of the following assumptions: When people tend to interpret their environment according to their basic values, these interpretations influence their attitudes, decision making, and behavior. Thus values can determine processes of social behavior and social change. On the other hand, environmentally induced behavioral tendencies of the person (including social sanctions and restrictions) can give rise to value change.

Thus, social change and value change should be studied as interrelated processes by taking into account two conditions. (1) the inner structure of the value system of the person and the society and its influence on the interpretation of the environment and the self; and (2) the kinds of environmental conditions that induce certain behavioral tendencies. 
This approach is different from a mechanistic view of individual behavior as it is proposed, e.g., by the assumption that socioeconomic development induces modern or post-materialist values. Instead, an interdependence between social change on a macrolevel and sociopsychological processes leading to value changes is assumed here. This interdependence still has to be clarified theoretically and empirically.

\section{REFERENCES}

ALMOND, G.A. Approaches to developmental causation. In: S. Almond, S.C. Flanagan, \& R.J. Mundt (Eds.). Crisis, choice, and change. Boston: Little, Brown, 1973, pp. 1-42.

AUSTIN, L. (Ed). Japan: The paradox of progress. New Haven/London: Yale University Press, 1976.

AZUMA, H. A cross cultural comparison of maternal control strategy with child's cognitive development. Paper presented at the International Congress of Psychology, Leipzig, 1980.

BARNES, S.H., KAASE, M., ALLERBECK, K.R., FARAH, B.G., HEUNKS, F., INGLEHART, R., JENNINGS, M.K., KLINGEMANN, H.B., MARSH, A., \& ROSENMAYER, L. (Eds.). Political action. Mass participation in five Western democracies. London: Sage Publications, 1979.

BELL, D. The coming of post-industrial society. New York: Basic Books, 1973.

BELLAH, R.N. Continuity and change in Japanese society. In: B. Barber \& A.

Inkeles (Eds.), Stability and social change. Boston: Little, Brown, 1971.

BENDIX, R. Nation-building and citizenship. New York: John Wiley, 1964.

BENDIX, R. Tradition and modernity reconsidered. Comparative Studies in Society and History, 1966/67, IX, 292-346.

BLACK, C.E. The modernization of Japan and Russia: $A$ comparative study. New York: Free Press, 1975.

CAUDILL, W., \& SCARR, H.A. Japanese value orientations and culture change. In: T.S. Lebra, \& W. P. Lebra (Eds.), Japanese culture and behavior. Selected readings. Honolulu: The University Press of Hawaii, 1974.

CONROY, M., HESS, R.D., AZUMA, H., \& KASHIWAGI, K. Maternal strategies for regulating children's behavior: Japanese and American families. Journal of Cross-Cultural Psychology, 1980, 2, 153-173.

DAWSON, J.L.M. Traditional versus Western attitudes in West Africa: The construction, validation and application of a measuring device. British Journal of Social and Clinical Psychology, 1967, 6, 81-96.

DER BUNDESMINISTER FUR JUGEND, FAMILIE UND GESUNDHEIT (Ed.). Zweiter Familienbericht. Bonn-Bad Godesberg, 1975.

$\mathrm{DOl}, \mathrm{T}$. The anatomy of dependence. Tokyo/New York/San Francisco: Kodansha International Lid., 1973.

DORE, R. British factory, Japanese factory. The origins of national diversity in industrial relations. Oxford: Oxford University Press, 1973.

EISENSTADT, S.N. Modernization: Protest and change. Englewood Cliffs Prentice-Hall, 1966.

EMNID-INSTITUT. EMNID-Information 1/2/1972. Bielefeld: EMNID, 1972. 
FLANAGAN, S.C. Value change and partisan change in Japan: The silent revolution revisited. Comparative Politics, 1979, 11, 253-278.

FLANAGAN, S.C. Value cleavages, economic cleavages, and the Japanese voter. American Journal of Political Science, 1980, 24, 178-206.

FOREIGN PRESS CENTER JAPAN (Ed.). The women of Japan-past and present. Tokyo, 1977.

GUSFIELD, J.R. Tradition and modernity: Misplaced polarities in the study of social change. American Journal of Sociology, 1967, 72, 351-362.

HAYASHI, C., NISHIRA, S., SUZUKI, T., MIZUNO, K., \& SAKAMOTO, Y. (Eds). Changing Japanese values-statistical surveys and analyses. Research Committee on the Study of the Japanese National Character. Tokyo: Institute of Statistical Mathematics, 1977.

HSU, F.L.K. Iemoto: The heart of Japan. New York/London: John Wiley, 1975.

IKE, N. Economic growth and intergenerational change in Japan. American Political Science Review, 1973, 67, 1194-1203.

INGLEHART, R. The silent revolution. Changing values and political style among Western publics. Princeton, N.J.: Princeton University Press, 1977.

INGLEHART, R. Socio-economic change and human value priorities. In: S.H. Barnes, M. Kaase, et al. (Eds.), Political action. Beverly Hills: Sage, 1979.

INGLEHART, R. Changing values in Japan and the West. Comparative Political Studies, 1982, 14, 445-479.

JANSEN, M.B. The Meiji State: 1868-1912. In: J.B. Crowley (Ed.), Modern East Asia: Essays in interpretation. New York, 1970.

KAASE, M. Political ideology, dissatisfaction, and protest. A micro theory of unconventional political behavior. In: K. v. Beyme (Ed.), German political studies, Vol. 2. London: Sage, 1976.

KAPLAN, M.A. (Ed.). Japan at the turning point. Prospects for the coming decade. Tokyo: Riverfield Inc., 1981.

LEPSIUS, M.R. Soziologische Theoreme über die Sozialstruktur der "Moderne" und die "Modernisierung." In: R. Koselleck (Ed.), Studien zum Beginn der modernen Welt. Stuttgart: Klett-Cotta, 1978.

LERNER, D. Modernization. In: International Encyclopedia of the Social Sciences, Vol. 10. New York: Macmillan Co. and Free Press, 1974, pp. 385-393.

LEVY, M.J. Modernization and the structure of societies. Princeton, N.J.: Princeton University Press, 1966.

LINHART, S. Arbeit, Freizeit und Familie in Japan. Eine Untersuchung der Lebensweise von Arbeitern und Angestellten in Großbetrieben. Wiesbaden: Harrassowitz, 1976.

LOERCHER, S. Zur Quantifizierung der "Sozialen Wohlfahrt" in Japan. Mitteilungen des Instituts für Asienkunde. Hamburg, 1976, 34.

MAE, M. Japanische Familienstruktur und Sozialisation. In: S. Yoshijima (Ed.), Sozialisation und Literatur. Ein interkultureller und interdisziplinärer Versuch. Interuniversitätsseminar für Deutsche und Japanische Kultur. Tokyo: Sansyusya Verlag, 1981.

MASLOW, A.H. Motivation and personality. New York: Harper, 1954.

MCFARLAND, H.N. The spirit of Japan: A thematic review of Japanese 
history. Paper prsented at the 10th International Conference on the Unity of Sciences. Seoul, Korea, November 1981.

MORSBACH, H. Some characteristics of Japanese interpersonal relations-a

Westerner's viewpoint. Paper presented at the Conference of the British Psychological Society, London, December 1977.

NAKANE, C. Japanese society. London: Weidenfeld \& Nicolson, 1970.

NISHIHIRA, S. Changed and unchanged characteristics of the Japanese. Japan Echo, 1974, 1, 21-32.

PHARR, S.J. Japan: Historical and contemporary perspectives. In: J.Z. Hiele, \& A.C. Smock (Eds.): Women. Roots and status in eight countries. New York: John Wiley, 1977.

PYE, L.W. Aspect of political culture: An analytic study. Boston: Little, Brown, 1966.

REISCHAUER, E.O. Japan: The story of a nation. New York: Alfred A. Knopf, 1970.

ROKEACH, M. The nature of human values. New York: Free Press, 1973.

SIARA, C.S. Komponenten der Wohlfahrt. Materialien zu Lebensbedingungen und Lebensqualität. Frankfurt: Campus, 1980.

SÖRBOM, P. The introduction of Western technology into China and Japan. A historical study of attitudes and reactions. Paper presented at the 10th International Conference on the Unity of the Sciences. Seoul, Korea, November 1981.

STEPHENSON, J.B. Is everyone going modern? A critique and a suggestion for measuring modernism. American Journal of Sociology, 1968, 74, 265-275.

TROMMSDORFF, G. Aspekte einer kulturvergleichenden Wertforschung. In: H. Klages, \& P. Kmieciak (Eds.), Wertwandel und gesellschaftlicher Wandel. Frankfurt: Campus, 1979.

TROMMSDORFF, G. Vergleich von Sozialisationsbedingungen in Japan und der Bundesrepublik. Paper presented at the Tagung für Familiensoziologie, Arnoldshain, November 1981.

TROMMSDORFF, G. Assessment of social change. Paper presented at the meeting of the International Sociological Association, Mexico City, August 1982.

TROMMSDORFF, G. Familiale Sozialisation im Kulturvergleich. Zeitschrift für Sozialisationsforschung und Erziehungssoziologie, 1984, 1, in press.

VOGEL, E.F. Japan as number 1. Cambridge, MA: Harvard University Press, 1979.

WEBER, M. Die protestantische Ethik. München: Siebenstern, 1965.

YOUTH BUREAU, PRIME MINISTER'S OFFICE OF JAPAN (Ed.). The youth of the world and Japan. The findings of the second world youth surver. Tokyo: Prime Minister's Office, 1978.

\section{ABSTRACT TRANSLATIONS}

$$
\text { Résumé }
$$

Cette Gtude porte sur le rapport existant entre l'évolution socio-économique et l'évolution des valeurs morales. En partant 
de données réunies au cours d'enquêtes faltes au Japon et en occident, on examine la validité de la thèse généralement admise selon laquelle les valeurs traditionelles et les valeurs modernes sont unidtmenionelles et s'excluent mutuellement. Et de falt, au Japon, certaines valeurs connaissent une évolution; mais d'autres, en revanche, sont 1mmuables. II semble que 1 'évolution des valeurs morales susclte des conflits dans certains sous-groupes, comme par example les femes et les jeunes. Il est possible de montrer, par une anslyse comparative, que certaines valeurs morales faponalses peuvent apparaftre "modernes" ou "post-materlalistes" a l'observateur occidental, alors qu'elles font partie du système de valeurs traditionnel du Japon. Ces valeurs "modernes" ont différentes fonctions, qul varient d'une civilisation $a$ l'autre. Sur la base de ces découvertes et de ces réflexions, on propose, pour l'étude de I'evolution social et de l'évolution des valeurs morales, un cadre théorique de référence qui prend en compte des processus évolutifs se produisant aussi bien à un macroniveau qu'à un micro-niveau.

\section{Resumen}

En este trabajo se estudia la relactón entre cambio socioeconómico y camblo de valores. Se examina la oplnion general de que valores tradfclonales y modernos son unidimensionales $y$ se excluyen entre $\mathbf{s} 1$, sobre 1 a base de datos reunidos en el Japon y de encuestas realizadas en el Occidente. Efectivamente, algunos valores en el Japón cambian, otros, por el contrarlo, se mantienen estables. Del proceso del cambio de valores parecen surgir conflictos para algunos subgrupos, como mujeres y jóvenes. Por medto de un anál1sis comparativo puede mostrarse que algunos valores japoneses, si bien aparecen para el observador occídental como "modernos" o "postmatertalistas", son sin embargo parte del sistema de valores japonés tradicional. Tales valores "modernos" cumplen en culturas diferentes functones completamente distintas. Sobre la base de estos datos y reflexiones se propone un marco teórico de relactón para el estudio del camblo soctal y del de valores, que incluye procesos de cambio tanto a macro como a micro-nivel. 